Acta vet. scand. $1981,22,189-197$.

From the Department of Reproductive Physiology and Pathology, Veterinary College of Norway, Oslo.

\title{
EFFECT OF PROLACTIN SUPPRESSION ON THE OVARIAN ACTIVITY IN THE LACTATING SOW*
}

\author{
By \\ Edvard Benjaminsen
}

\begin{abstract}
BENJAMINSEN, EDVARD: Effect of prolactin suppression on the ovarian activity in the lactating sow. Acta vet. scand. 1981, 22, 189197. - The effect of prolactin suppression during lactation was studied in 6 sows nursing 5-10 piglets. In order to inhibit prolactin secretion a dopamin agonist (bromocriptine, Parlodel $B$ "Sandoz") was given per os from about 4 weeks after parturition until weaning 9-17 days later. Plasma prolactin and plasma progesterone were determined by radioimmunoassays. In all animals plasma prolactin was suppressed during the bromocriptine treatment. Two sows resumed ovarian activity during treatment as indicated by elevated plasma progesterone, probably as a result of the low plasma prolactin levels. The results suggest that the elevated plasma prolactin levels during lactation is one of the factors responsible for lactational anoestrus in the sow.
\end{abstract}

prolactin; bromocriptine; sow; lactation; lactation al a noestrus.

In the sow ovarian activity is inhibited during lactation. Follicular growth is suppressed, corpora lutea are absent (Crighton \& Lamming 1969), and plasma progesterone and plasma oestrogen levels stay low (Ash \& Heap 1975, Baldwin \& Stabenfeldt 1975).

The underlying mechanism is not fully understood. Pituitary FSH levels are equal to those found before oestrus, while pituitary LH content is low (Crighton d Lamming). The plasma con-

- Financial support was given by the Norwegian Agricultural Research Council. 
centrations of $\mathrm{LH}$ are also low during lactation and the pulsatile LH secretion is absent (Parvizi et al. 1976). Ovariectomy during lactation or just prior to parturition (day 112) does not lead to increased pituitary LH or plasma LH concentrations, as when performed earlier in pregnancy or during the oestrous cycle (Crighton \& Lamming, Parvizi et al.). This indicates the presence of a gonadotrophin inhibitory factor of extraovarian origin during lactation.

Prolactin seems to be involved in suppression of ovarian activity during lactation in several mammalian species (McNeilly 1980). It is well established that lactating sows have high plasma prolactin levels (Landeghem \& Wiel 1978, Bevers et al. 1978), but the significance of this in regard to reproductive function is not fully known.

In the present work prolactin secretion was suppressed in lactating sows by means of a dopamin agonist, and the effect of this treatment on the ovarian function was studied.

\section{MATERIALS AND METHODS}

Six lactating sows of the Norwegian landrace breed were used. The sows were nursing 5-10 piglets. In order to inhibit prolactin release a dopamin agonist (bromocriptine, Parlodel $\AA$ "Sandoz") was given per os from about 4 weeks (25 or 29 days) after parturition until weaning. On the first day, each sow received $10 \mathrm{mg}$ bromocriptine in the morning and the same amount in the afternoon (concomitant with feeding). Later the dosage was reduced to $7.5 \mathrm{mg}$ bromocriptine twice a day. The sows were weaned $34-45$ days after farrowing.

By puncturing the jugular vein the sows were blood sampled, usually twice a week, during the lactation and in the post weaning period. The method used for blood sampling has been found not to affect plasma prolactin levels to any noticeable extent (Benjaminsen 1981).

Plasma prolactin was determined by a RIA developed by Landeghem \& Wiel (1978) with the modifications described by Benjaminsen. Ovarian function was recorded by plasma progesterone determinations. The RIA used has been described previously (Benjaminsen \& Karlberg 1981). The occurrence of oestrous symptoms and signs of reduced milk production during treatment were recorded by the stockman. 


\section{RESULTS}

In all of the animals plasma prolactin decreased during bromocriptine treatment to values typical for the post weaning period. In one sow (No. 1238, Fig. 1) the prolactin values, after an initial fall, increased considerably during treatment. In this sow, and also probably in sows Nos. 1173 and 1206 (Fig. 2), a second decrease in prolactin values was observed after weaning.
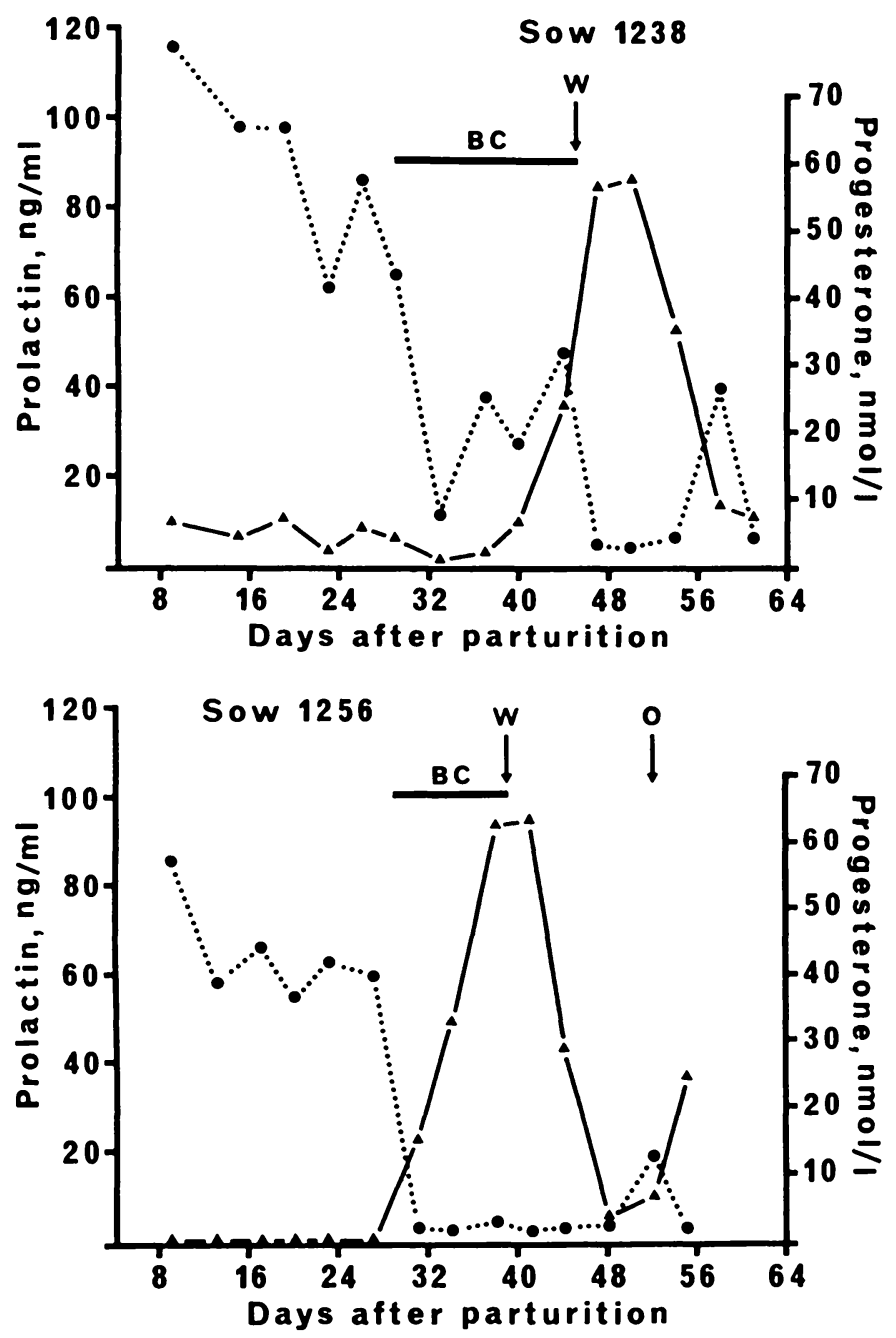

F i g u r e 1. Plasma prolactin $(\bullet \ldots . . \bullet)$ and plasma progesterone $(\triangle-\triangle)$ during lactation and after weaning in 2 sows treated with bromocriptine $(\mathrm{BC})$. The progesterone profiles indicate that ovarian activity was resumed during treatment. W: weaning, 0 : overt oestrus. 

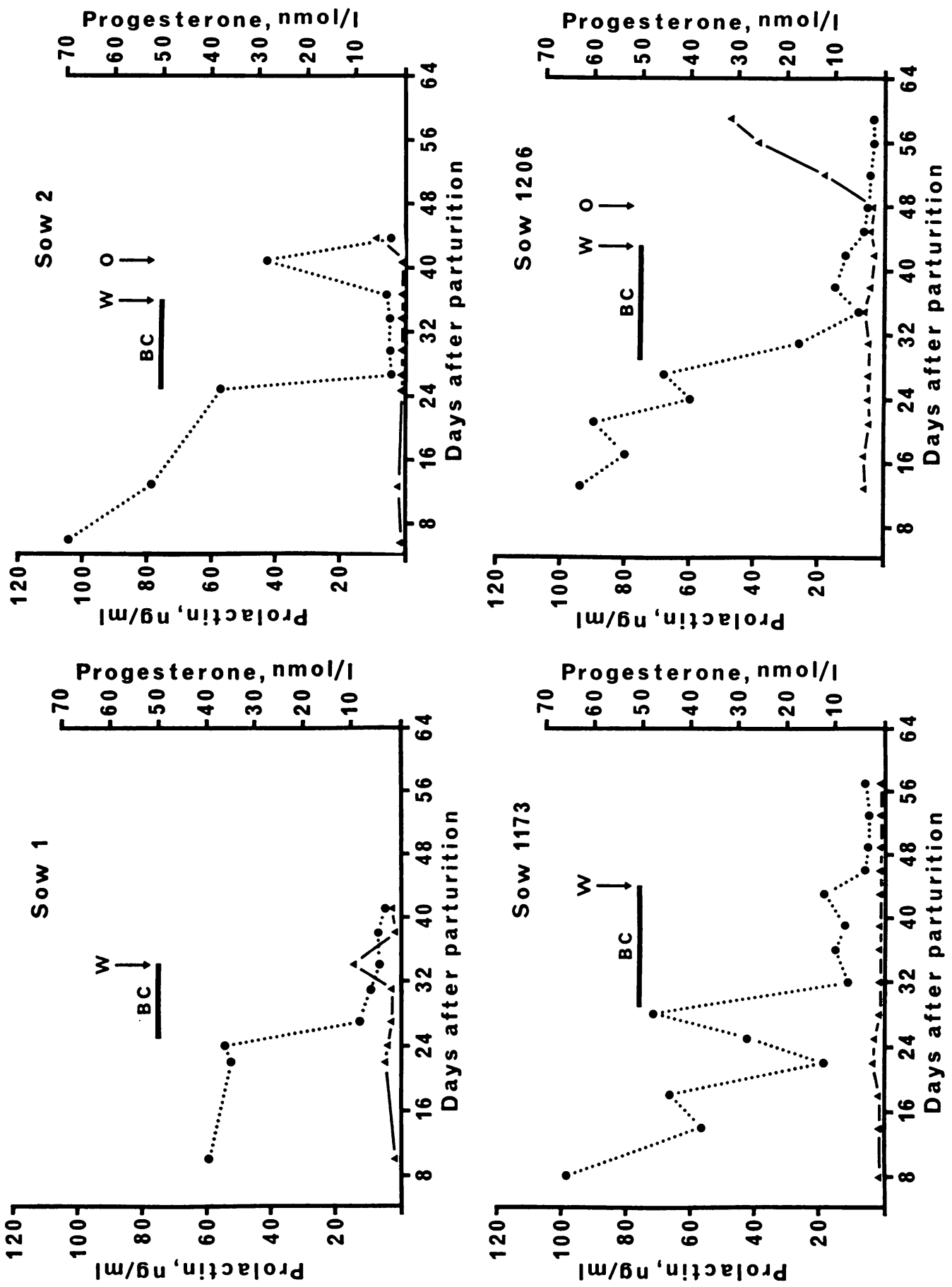

Figure 2. Plasma prolactin $(\bullet \ldots \ldots \cdot \bullet)$ and plasma progesterone $(\Delta-\Delta)$ during lactation and after weaning in 4 sows treated with bromocriptine $(\mathrm{BC})$. None of the sows resumed ovarian activity during treatment. W: weaning, 0 : overt oestrus. 
Two of the bromocriptine treated sows formed corpora lutea during lactation, as indicated by elevated plasma progesterone levels (Fig. 1). No oestrous symptoms, however, were observed in connection with the ovulation probably having taken place. The other 4 sows did not resume ovarian function during lactation (Fig. 2). Two of them (Nos. 2 and 1206) showed oestrus a few days after weaning and formed corpora lutea, while 2 were not observed in heat within 10 days after weaning. Sows Nos. 1, 2 and 1173 were slaughtered after the experimental period, and the post mortem ovarian findings were in agreement with the clinical recordings and the progesterone values.

Bromocriptine treated sows did not show any sign of discomfort during the treatment period. Reduced udder size or alterations in suckling behavior, indicating decreased milk secretion, were not observed. Piglets from treated sows had the same weight 6 weeks after birth as piglets from other litters in the same herd.

\section{DISCUSSION}

The plasma prolactin values found during lactation before the bromocriptine treatment and after weaning are in concordance with levels reported by Landeghem \& Wiel (1978). In all species tested bromocriptine is a potent suppressor of prolactin secretion (Flückiger 1978), and in women this effect is of great therapeutical importance (Baird 1979). The dosage chosen in the present investigation may have been somewhat low since some elevated prolactin values were found during treatment. Willemse et al. (1980) achieved prevention of the preparturient rise of prolactin in gilts by giving $10 \mathrm{mg}$ bromocriptine orally every 6 hours. Our results indicate that the minimum dosage for effective prolactin suppression in suckled sows probably is about $10 \mathrm{mg}$ twice a day.

In 2 of the bromocriptine treated sows the progesterone levels suggest that ovulation, succeeded by a normal luteal phase, had occurred during lactation. The resumption of the ovarian activity in these sows was probably permitted by the low prolactin levels (Fig. 1). In sow No. 1238 some high prolactin values were found during treatment, but the initial drop seemed to have been sufficient for the ovarian activity to be resumed. The high value in this sow on day 37 after parturition might have been caused 
by a preovulatory prolactin surge previously observed in cycling gilts (Landeghem \& Wiel 1977). The prolactin peak in the same sow on day 58 (Fig. 1) and those in sow No. 1256 (Fig. 1) and sow No. 2 (Fig. 2) on the day of oestrus were probably also caused by preovulatory prolactin surges.

The mechanism by which prolactin could exert its inhibitory effect on ovarian activity in the sow, has been the subject of several studies. Veldhuis et al. (1980) showed that prolactin inhibited progesterone production in porcine granulosa cells from small, immature follicles. This indicates an inhibitory effect of prolactin at the ovarian level. Other reports deal with the possibility of an inhibitory effect at the hypothalamic/hypophyseal level. Low plasma LH levels during lactation have been demonstrated (Parvizi et al. 1976), and reduction of plasma prolactin, by removing the piglets temporarily was followed by an increase in plasma $\mathrm{LH}$ (Wiel et al. 1978). Injection of GnRH is reported to give a normal LH response (Wiel et al.) irrespective of plasma prolactin levels (Willemse et al. 1979). These results suggest that prolactin may have a gonadotrophin inhibitory effect at the hypothalamic level. In various species (rat, sheep, man) prolactin seems to interfere with the gonadal steroid feedback mechanism in the hypothalamus (McNeilly 1980). A similar effect of prolactin could exist in the sow. Elsaesser \& Parvizi (1980) have recently reported a blockade of the LH stimulatory oestrogen feedback mechanism in the lactating sow.

In sow No. 1256 the ovulation seemed to occur at the beginning of the bromocriptine treatment (Fig. 1). This indicates that mature follicles were present in this sow before treatment. Crighton \& Lamming (1969) did not find follicles of preovulatory size during lactation. However, Edquist et al. (1974) reported occasional periods of elevated oestrogen levels in peripheral plasma in some lactating sows. These oestrogen peaks were not accompanied by ovulation, but indicate that mature follicles may be present in the ovaries of lactating sows.

In 4 of the bromocriptine treated sows ovarian activity was not resumed during lactation, even though prolactin levels decreased to values comparable with those found in the post weaning period (Fig. 2). This suggests that factors other than prolactin are implicated in the lactational anoestrus in the sow. One such factor could be the suckling stimulus. 
Since hyperprolactinaemia in lactation is dependent upon the suckling stimulus, it is difficult to differentiate between their relative effects. There is evidence that hyperprolactinaemia is most important in the ewe (Kann et al. 1977) and in women (McNeilly 1979), but not necessarily in the cow (Peters et al. 1979). In ovariectomized, lactating rats suppression of LH and FSH is dependent of the suckling stimulus as well of the hyperprolactinaemia (Smith 1978), thus indicating that both factors are important for inhibition of ovarian cyclicity during lactation. The present study indicates that a similar condition may exist in the sow.

\section{AGKNOWLEDGEMENTS}

The antiserum was produced and provided by Dr. D. F. M. van de Wiel, Research Institute for Animal Husbandry, "Schoonoord", The Netherlands. Porcine prolactin was provided by the National Pituitary Agency, USA, through the kind cooperation of Dr. R. Mäkelä, University of Helsinki. Iodination was performed at the Hormone and Isotope Laboratory, Aker Hospital, Oslo. The animals were made available by the Department of Animal Genetics and Breeding, Agricultural University of Norway.

\section{REFERENCES}

Ash, R. W. \& R. B. Heap: Oestrogen, progesterone and corticosteroid concentrations in peripheral plasma of sows during pregnancy, parturition, lactation and after weaning. J. Endocr. 1975, 64, $141-154$.

Baird, D. T.: Endocrinology of female infertility. Br. med. Bull. 1979, $35,193-198$.

Baldwin, D. M. \& G. H. Stabenfeldt: Endocrine change in pig during late pregnancy, parturition and lactation. Biol. Reprod. 1975, $12,508-515$.

Benjaminsen, E.: Plasma prolactin in the sow with emphasis on variation in resumption of ovarian activity after weaning. Acta vet. scand. 1981, 22, 67-77.

Benjaminsen, E. \& K. Karlberg: Post weaning oestrus and luteal function in primiparous and pluriparous sows. Res. Vet. Sci. 1981, $30,318-322$.

Bevers, M. M., A. H. Willemse \& Th. A. M. Kruip: Plasma prolactin levels in the sow during lactation and the postweaning period as measured by radioimmunoassay. Biol. Reprod. 1978, 19, $628-634$.

Crighton, D. B. \& G. E. Lamming: The lactational anoestrus of the sow: The status of the anterior pituitary-ovarian system during lactation and after weaning. J. Endocr. 1969, 43, 507-519. 
Edquist, L. E., S. Einarsson \& I. Settergren: Ovarian activity and peripheral plasma levels of oestrogens and progesterone in the lactating sow. Theriogenology 1974, 1, 43-49.

Elsaesser, F. \& N. Parvizi: Partial recovery of the stimulatory oestrogen feedback action on $\mathrm{LH}$ release during lactation in the pig. J. Reprod. Fert. 1980, 59, 63-67.

Flückiger, E.: Effects of bromocriptine on the hypothalamo-pituitary axis. Acta Endocr. (Kbh.) 1978, suppl. 216, 88, 111-117.

Kann, G., J. Martinet \& A. Schirar: Modifications of gonadotrophin secretion during natural and artificial hyperprolactinaemia in the ewe. In Crosignani, P. G. \& C. Robyn, eds.: Prolactin and Human Reproduction. Academic Press, London 1977, pp. 47-59.

Landeghem, A. A. J. van \& D. F. M. van de Wiel: Plasma prolactin levels in gilts during the oestrous cycle and at hourly intervals around the time of oestrus. Acta Endocr. (Kbh.) 1977, suppl. $212,85,233$.

Landeghem, A. A. J. van \& D. F. M. van de Wiel: Radioimmunoassay for porcine prolactin: Plasma levels during lactation, suckling and weaning and after TRH administration. Acta Endocr. (Kbh.) 1978, 88, 653-667.

McNeilly, A. S.: Effects of lactation on fertility. Br. med. Bull. 1979, $35,151-154$.

McNeilly, A. S.: Prolactin and the control of gonadotrophin secretion in the female. J. Reprod. Fert. $1980,58,537-549$.

Parvizi, N., F. Elsaesser, D. Smidt \& F. Ellendorff: Plasma luteinizing hormone and progesterone in the adult female pig during the oestrous cycle, late pregnancy and lactation, and after ovariectomy and pentobarbitone treatment. J. Endocr. 1976, 69, 193203.

Peters, A. R., S. Vyvoda \& G. E. Lamming: Comparison of plasma prolactin levels in the milked and suckling cow. J. Endocr. 1979, $83,27-28$.

Smith, M. S.: The relative contribution of suckling and prolactin to the inhibition of gonadotrophin secretion during lactation in the rat. Biol. Reprod. 1978, 19, 77-83.

Veldhuis, J. D., P. Klase \& J. M. Hammond: Divergent effects of prolactin upon steroidogenesis by porcine granulosa cells in vitro: Influence of cytodifferentiation. Endocrinology 1980, 107, $42-46$.

Wiel, D. F. M. van de, A. A. J. van Landeghem, M. M. Bevers \& A. H. Willemse: Endocrine control of pituitary and ovarian function during lactation in the sow. In Gaillard, P. J. and H. H. Boer, eds.: Comparative Endocrinology. Elsevier/North-Holland Biomedical Press, Amsterdam 1978, p. 378.

Willemse, A. H., M. M. Bevers, D. F. M. van de Wiel, Th. A. M. Kruip \& G. Eikelenboom: The effect of synthetic LH-RH on the LH release in the lactating sow. Proc. Int. Symp. on Central and Peripheral Regulation of Prolactin Function. Taormina 1979, pp. $63-64$. 
Willemse, A. H., M. M. Bevers, Th. A. M. Kruip, D. F. M. van de Wiel \& G. Eikelenboom: The role of prolactin in suppression of ovarian activity in the lactating sow. Proc. IPVS Congr., Copenhagen 1980 , p. 23.

\section{SAMMENDRAG}

Virkning av prolaktinsuppresjon på ovarialfunksjonen hos lakterende purker.

Virkningen av prolaktinsuppresjon under laktasjonen ble unders $\varnothing$ kt hos 6 purker, som hadde 5-10 unger. For á hemme prolaktinsekresjonen ble purkene gitt en dopamin agonist (bromocriptin, Parlodel@ „Sandoz") per os fra ca. 4 uker etter grising til avvenning 9 til 17 dager senere. Plasma prolaktin og plasma progesteron ble bestemt ved hjelp av radioimmunoassays. Hos alle dyrene gikk plasma prolaktinverdiene ned under bromocriptin behandlingen. Progesteronprofilene indikerte at 2 purker ovulerte og dannet gule legemer under laktasjonen, sannsynligvis som et resultat av de lave prolaktinverdiene. Unders $\varnothing$ kelsen viser at h $\varnothing$ yt plasma prolaktin trolig er en av årsakene til laktasjons an $\varnothing$ strus hos purke.

(Received January 5, 1981).

Reprints may be requested from: Edvard Benjaminsen, the Department of Reproductive Physiology and Pathology, Veterinary College of Norway, P.0. Box 8146, Dep., Oslo 1, Norway. 